\title{
The terrestrial Gastropoda Megalobulimus abbreviatus as a useful model for nociceptive experiments. Effects of morphine and naloxone on thermal avoidance behavior
}

\author{
M. Achaval ${ }^{1}$, M.A.P. Penha' ${ }^{1}$, \\ A. Swarowsky ${ }^{1}$, P. Rigon ${ }^{1}$, \\ L.L. Xavier ${ }^{1}$, G.G. Viola ${ }^{1}$ and \\ D.M. Zancan²
}

\author{
${ }^{1}$ Laboratório de Histofisiologia Comparada, Departamento de Ciências Morfológicas, \\ and ${ }^{2}$ Laboratório de Neurobiologia, Departamento de Fisiologia, \\ Instituto de Ciências Básicas da Saúde, Universidade Federal do Rio Grande do Sul, \\ Porto Alegre, RS, Brasil
}

\section{Correspondence}

M. Achaval

Laboratório de Histofisiologia

Comparada

Departamento de Ciências

Morfológicas, ICBS, UFRGS

R. Sarmento Leite, 500

90050-070 Porto Alegre, RS

Brasil

Fax: +55-51-3316-3092

E-mail: achaval@ufrgs.br

Research supported by

UFRGS/FINEP (No. 66.91.0509.00)

and CNPq.

Received January 30, 2004

Accepted October 13, 2004

\section{Abstract}

We describe the behavior of the snail Megalobulimus abbreviatus upon receiving thermal stimuli and the effects of pretreatment with morphine and naloxone on behavior after a thermal stimulus, in order to establish a useful model for nociceptive experiments. Snails submitted to non-functional $\left(22^{\circ} \mathrm{C}\right)$ and non-thermal hot-plate stress $\left(30^{\circ} \mathrm{C}\right)$ only displayed exploratory behavior. However, the animals submitted to a thermal stimulus $\left(50^{\circ} \mathrm{C}\right)$ displayed biphasic avoidance behavior. Latency was measured from the time the animal was placed on the hot plate to the time when the animal lifted the head-foot complex $1 \mathrm{~cm}$ from the substrate, indicating aversive thermal behavior. Other animals were pretreated with morphine $(5,10,20 \mathrm{mg} / \mathrm{kg})$ or naloxone $(2.5,5.0,7.5 \mathrm{mg} / \mathrm{kg}) 15 \mathrm{~min}$ prior to receiving a thermal stimulus $\left(50^{\circ} \mathrm{C} ; \mathrm{N}=9\right.$ in each group). The results (means $\pm \mathrm{SD}$ ) showed an extremely significant difference in response latency between the group treated with $20 \mathrm{mg} / \mathrm{kg}$ morphine $(63.18 \pm 14.47 \mathrm{~s})$ and the other experimental groups $(\mathrm{P}<0.001)$. With $2.5 \mathrm{mg} / \mathrm{kg}(16.26 \pm$ $3.19 \mathrm{~s}), 5.0 \mathrm{mg} / \mathrm{kg}(11.53 \pm 1.64 \mathrm{~s})$ and $7.5 \mathrm{mg} / \mathrm{kg}$ naloxone $(7.38 \pm 1.6$ $\mathrm{s})$, there was a significant, not dose-dependent decrease in latency compared to the control ( $33.44 \pm 8.53 \mathrm{~s})$ and saline groups $(29.1 \pm 9.91$ s). No statistically significant difference was found between the naloxone-treated groups. With naloxone plus morphine, there was a significant decrease in latency when compared to all other groups (minimum $64 \%$ in the saline group and maximum $83.2 \%$ decrease in the morphine group). These results provide evidence of the involvement of endogenous opioid peptides in the control of thermal withdrawal behavior in this snail, and reveal a stereotyped and reproducible avoidance behavior for this snail species, which could be studied in other pharmacological and neurophysiological studies.
Key words

- Snail

- Thermal avoidance

- Nociception

- Morphine

- Naloxone 


\section{Introduction}

According to Sherrington, the capacity of animals to detect and react to stimuli that may compromise their integrity is embodied in the term "nociception" cited in Ref. 1 . The ability to respond to aversive environmental stimuli is a basic characteristic of animals and this adaptive animal behavior implies the presence of nociceptors to detect the aversive nature of the stimuli and effectors which respond to the sensory input with reflex and/or non-reflex behavior. Descriptions of postures and movements associated with nociception and avoidance behavior can be quantitative and objective if we refrain from interpreting them with connotations of human experience. The avoidance behavior of snails, such as Cepaea nemoralis, Megalobulimus sanctipauli and Aplysia californica has been described (1-4). In avoidance behavior, the snails presented a withdrawal reaction accompanied by mucus secretion to all kinds of noxious stimuli. In response to moderately intense tactile stimulation $\left(15-40 \mathrm{~g} / \mathrm{mm}^{2}\right)$ the snail remained outside the shell, locomotion ceased, and the animal showed pneumostome closure, tentacle contraction, head withdrawal, and a latency of about $0.2 \mathrm{~s}$. In response to a strong noxious stimulus, the snails showed all the aforementioned reactions and retraction of the whole body into the shell (5). In response to thermal stimuli, within a few seconds $C$. nemoralis $\left(40^{\circ} \mathrm{C}\right)$ and $M$. sanctipauli $\left(52^{\circ} \mathrm{C}\right)$ showed aversive behavior characterized by lifting the anterior regions of the head-foot (H-F) complex. This behavior is not detected in snails at room temperature or at lower temperatures such as $30-33^{\circ} \mathrm{C}(4,6)$.

Moreover, the administration of morphine sulfate, methionine-enkephalin or ß-endorphin resulted in a significant increase in the latency of thermal avoidance behavior $(4,6)$. Also, the increased latency resulting from morphine administration to $C$. nemoralis, Limax maximus and $M$. sanctipauli after a thermal stimulus can be suppressed by the opiate antagonist, naloxone $(3,4,7)$. Thus, in these gastropods the ability of the nonselective opiate antagonist naloxone to produce a complete blockade of morphine analgesia indicates that a $\mu$ receptor is related to this behavior $(4,8)$. Naloxone alone decreases the latency of the thermal stress (2). It was also demonstrated that thermal stimulus-induced analgesia was blocked by a $\delta$ antagonist (9). In addition, enkephalin immunoreactivity was identified in the central nervous system of different snails such as A. californica, Lymnaea stagnalis, Helix pomatia, and M. abbreviatus $(10,11)$.

The present study reports the avoidance behavior of $M$. abbreviatus, as well as the effects of morphine and its antagonist naloxone on this snail after a thermal stimulus. This study represents a contribution as a starting point for the functional detection of the nociceptive circuit $(12,13)$ present in this snail.

\section{Material and Methods}

\section{Animals}

Adult land snails, Megalobulimus abbreviatus (Becquaert, 1948), previously called M. oblongus (Müller, 1774), with shell lengths of 65-80 mm and weighing 50-79 g were collected in Charqueadas county, State of Rio Grande do Sul, Brazil. The animals were kept in a screened terrarium, subjected to normal annual light and temperature variations, and fed lettuce and water ad libitum. To minimize the novelty stress $(4,9,14)$, the satiated snails were allowed to rehydrate in individual humid chambers $2 \mathrm{~h}$ prior to the experiments. Pharmacological agents were dissolved in saline and injected into the intrahemocelic cavity through the anterior ventral zone of the foot. Fifteen minutes after the injection, the snails were submitted to a thermal stimulus. To avoid sensitization or habituation, each snail was used only 
once. Additionally, to avoid the probable effect of the lack of humidity on the substrate during exposure of the snails to the hot plate, a plastic film covered with $10 \mathrm{ml}$ of distilled water was placed over the plate. It was then necessary to wait for the plate to reacquire the predetermined temperature. All the experimental procedures were carried out during the mid-light period (14-17 h).

\section{Experimental procedures}

The nociceptive thresholds of individual snails were determined by measuring the latency of their avoidance or withdrawal behaviors (15) in response to the thermal stimulus. The measurement of latency started at the time when the snail was placed on the hot plate and ended as soon as the animal lifted the H-F complex to a minimum of $1 \mathrm{~cm}$ (4). Individual hydrated snails were placed on a hot plate (model-DS37, Socrel, Comerio, $\mathrm{VA}$, Italy) at $22^{\circ} \mathrm{C}$ ambient temperature (nonfunctional hot plate), at a non-stressful thermal condition of $30^{\circ} \mathrm{C}$ or at a stressful thermal condition of $50^{\circ} \mathrm{C}(\mathrm{N}=9$ in each group) and the response latency of their avoidance behavior was determined.

In order to determine the variation of the thermal stress $\left(50^{\circ} \mathrm{C}\right)$ response latency to morphine and naloxone, individual hydrated snails were injected with pharmacological drugs, as described below, $15 \mathrm{~min}$ prior to thermal stimuli. After their response latencies were determined, the snails were quickly removed from the hot plate.

Four groups of hydrated snails $(\mathrm{N}=9$ in each) were injected with morphine sulfate (Cristália do Brasil S/A, São Paulo, SP, Brazil) at concentrations of 5.0, 10.0, and 20.0 $\mathrm{mg} / \mathrm{kg}$ body weight or saline $(1.0 \mathrm{ml})$ before being placed on a heated surface $\left(50^{\circ} \mathrm{C}\right)$. Another group (control; $\mathrm{N}=9$ ) of untreated hydrated snails was also placed on a heated surface (16)

Latencies were also determined for animals treated with the morphine antagonist naloxone. Four groups $(\mathrm{N}=9$ in each) were injected with naloxone hydrochloride (Cristália) at concentrations of $2.5,5.0$ or $7.5 \mathrm{mg} /$ $\mathrm{kg}$ body weight, or with saline $(1.0 \mathrm{ml})$ before being placed on a heated surface $\left(50^{\circ} \mathrm{C}\right)$. Another group of untreated hydrated snails (control, $\mathrm{N}=9$ ) was also placed on a heated surface.

To reverse the action of morphine 9 snails were pretreated with naloxone hydrochloride $(5.0 \mathrm{mg} / \mathrm{kg}$ body weight $)$ and after $5 \mathrm{~min}$ were injected with morphine sulfate $(20.0$ $\mathrm{mg} / \mathrm{kg}$ body weight); after another $15 \mathrm{~min}$, the snails were placed on a heated surface $\left(50^{\circ} \mathrm{C}\right)$. Another group was injected with 1.0 $\mathrm{ml}$ saline $(\mathrm{N}=9)$.

\section{Statistical analysis}

Data were analyzed statistically by analysis of variance (ANOVA) followed by the Tukey test, with the level of significance set at $\mathrm{P}<0.05$. The analyses were carried out using the SPSS 7.0 software.

\section{Results}

\section{Nociceptive response}

The snails placed on the nonfunctional hot plate $\left(22^{\circ} \mathrm{C}\right)$ displayed only exploratory behavior, with their H-F complex remaining extended, touching the substrate and showing slow undulatory waves in the parapodial region. In the anterior region of the H-F complex, the parapodium was lifted. Protracted labial palps and oral tentacles were in constant movement and when they touched the substrate they displayed a quick retraction. Immediately, they again performed tentacular palpation of the substrate, exploring the environment. The snails exhibited a slight elevation of the anterior aspect of the head and then turning movements of the body without turning movements of the shell, but did not show any locomotory activity. Thus, the snails exposed to $22^{\circ} \mathrm{C}$ displayed neither 
Figure 1. Schematic representation of the snail Megalobulimus abbreviatus in the first phase of aversive behavior. Note the retracted oral tentacles and labial palps and the triangular aspect of the head-foot complex when the snail was placed on the hot plate.

Figure 2. Schematic representation of the second phase of the aversive behavior of the snail Megalobulimus abbreviatus. Note that, after protraction, the snail exhibited anterior lifting of the head-foot complex $1 \mathrm{~cm}$ from the substrate, characterizing aversive behavior. foot lifting behavior nor locomotion. No modification was detected in mucus secretion. The snails were observed for $300 \mathrm{~s}$ on the hot plate, always displaying the same behavior, which was also observed in snails submitted to a non-thermal stress of $30^{\circ} \mathrm{C}$.

The snails submitted to a thermal stimulus of $50^{\circ} \mathrm{C}$ displayed biphasic avoidance behavior, exhibiting a retraction of the body into the shell in the first phase and protrac-
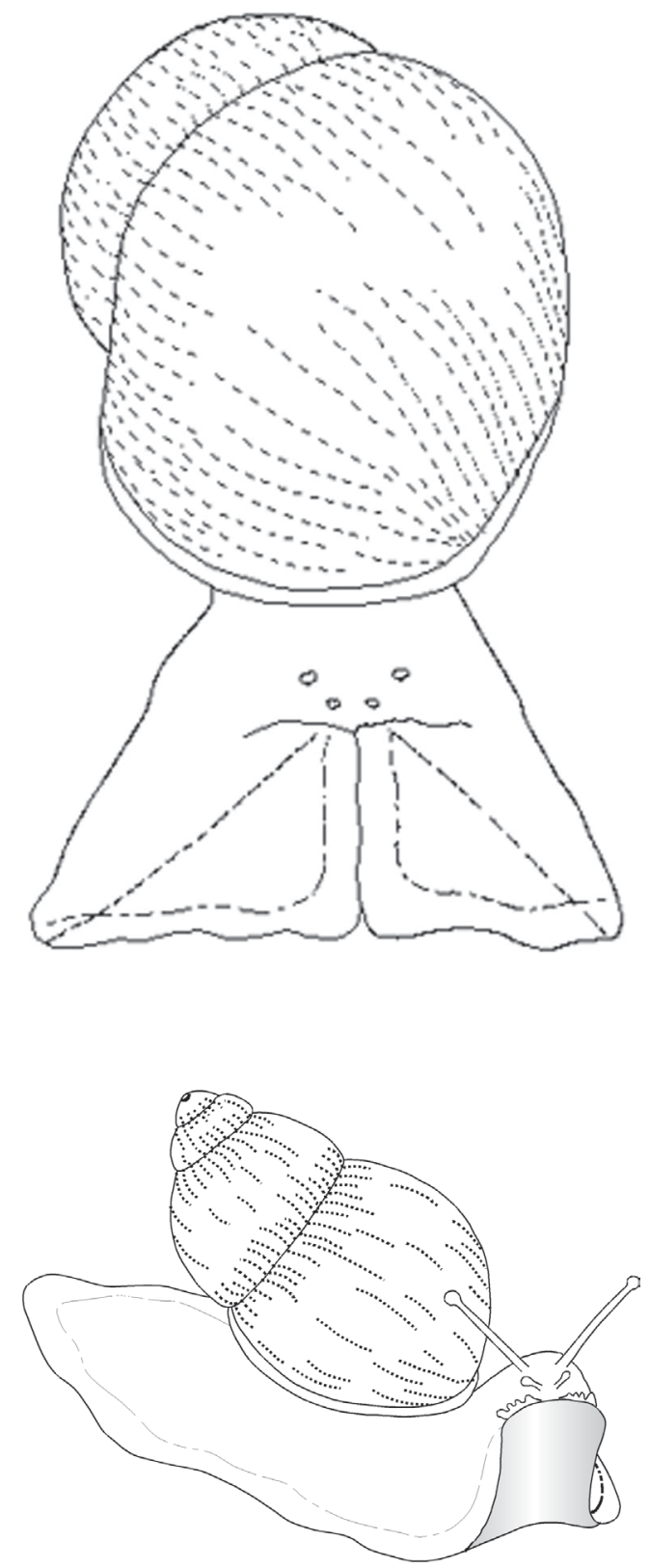

tion and searching movements in the second (17).

First phase. When placed on the hot plate, M. abbreviatus exhibited an extended foot which was immediately retracted laterally. At the same time, the oral tentacles and labial palps retracted and this movement was followed by a medial-ventral retraction of the H-F complex, beginning at the rostral region and extending to the caudal region. Thus, only the lateral portion of the foot remained in contact with the substrate, with the occurrence of a partial retraction of the body into the shell. When the snail was observed from the anterior region, the H-F complex showed a triangular aspect (Figure 1).

Second phase. After $25 \mathrm{~s}$, on average, the retracted oral tentacles and labial palps began to protract and the snail displayed searching movements followed by lateral parapodial waves characterizing exploratory behavior. Subsequently, the animals exhibited anterior lifting of the H-F complex $1 \mathrm{~cm}$ or more from the substrate. The average latency of the avoidance behavior response or of the H-F complex elevation to a height of 1 $\mathrm{cm}$ was $33 \mathrm{~s}$. After the lifting of the H-F complex, the rostral portion of the head turned (Figure 2). All the animals in this group exhibited foot swelling and intense secretion of yellowish mucus.

\section{Nociceptive responses after morphine and naloxone administration}

Administration of different concentrations of morphine before the thermal stress $\left(50^{\circ} \mathrm{C}\right)$ promoted an increased latency of withdrawal behavior in the snails, with the oral tentacles and optic tentacles remaining partially retracted and flaccid.

The animals treated with 5.0, 10.0 or $20.0 \mathrm{mg} / \mathrm{kg}$ body weight morphine displayed a partial retraction of the H-F complex, less intense than that observed in control snails. In the second phase of avoidance behavior, the snails showed a partial protraction of 
flaccid palps and oral tentacles.

The snails injected with a higher dose of morphine $(20.0 \mathrm{mg} / \mathrm{kg}$ body weight $)$ showed pedal muscle rigidity before being placed on the hot plate. The optic and oral tentacles of these snails remained protracted and flaccid throughout all phases of the test. All animals in this group that received morphine before the thermal aversive stimulus presented a thick yellowish mucus secretion. With this higher morphine dose the response latency was significantly longer (means $\pm \mathrm{SD}, 63.18$ $\pm 14.47 \mathrm{~s})$ than those recorded with $5.0 \mathrm{mg} /$ $\mathrm{kg}(34.22 \pm 12.7 \mathrm{~s})$ or $10.0 \mathrm{mg} / \mathrm{kg}(34.8 \pm$ $7.78 \mathrm{~s}$ ) of morphine. Nevertheless, there was no significant difference in the response latency between snails that received 5.0 or $10.0 \mathrm{mg} / \mathrm{kg}$ body weight morphine (Figure $3)$. The snails only injected with saline displayed an response latency of $29.1 \pm 9.91 \mathrm{~s}$ and exhibited a similar behavior to the control group (33.44 $\pm 8.53 \mathrm{~s})$. Furthermore, there was no significant difference between the groups receiving saline or 5.0 or $10.0 \mathrm{mg} /$ $\mathrm{kg}$ body weight morphine in terms of response latency.

The snails that received naloxone (2.5, $5.0,7.5 \mathrm{mg} / \mathrm{kg}$ body weight) exhibited biphasic behavior, faster than that observed in control animals. However, lifting of the H-F complex $1 \mathrm{~cm}$ above the substrate occurred at $16.26 \pm 3.19,11.5 \pm 1.64$ and 7.38 $\pm 1.6 \mathrm{~s}$, respectively, for each of the above doses. The latency of the response obtained with these naloxone doses was significantly shorter than that of the control $(33.44 \pm 8.53$ $\mathrm{s} ; \mathrm{P}<0.01$ for dose of $2.5 \mathrm{mg}$ and $\mathrm{P}<0.001$ for doses of 5.0 and $7.5 \mathrm{mg} / \mathrm{kg}$ ) and saline groups $(29.1 \pm 9.91 \mathrm{~s} ; \mathrm{P}<0.05$ for dose of $2.5 \mathrm{mg} / \mathrm{kg}, \mathrm{P}<0.01$ for dose of $5.0 \mathrm{mg} / \mathrm{kg}$ and $\mathrm{P}<0.001$ for dose of $7.5 \mathrm{mg} / \mathrm{kg}$ ), but there were no significant differences between the three naloxone-treated groups (Figure 4). These naloxone doses did not interfere with motor behavior. The snails exhibited retracted and flaccid oral and optic tentacles, similar to those of the animals treated with morphine.

The snails pre-treated with naloxone (5.0 $\mathrm{mg} / \mathrm{kg}$ body weight) and injected with morphine $(20.0 \mathrm{mg} / \mathrm{kg}$ body weight) $5 \mathrm{~min}$ later displayed both phases of the avoidance behavior, with an average response latency of $10.6 \mathrm{~s}$. The response latency of this group

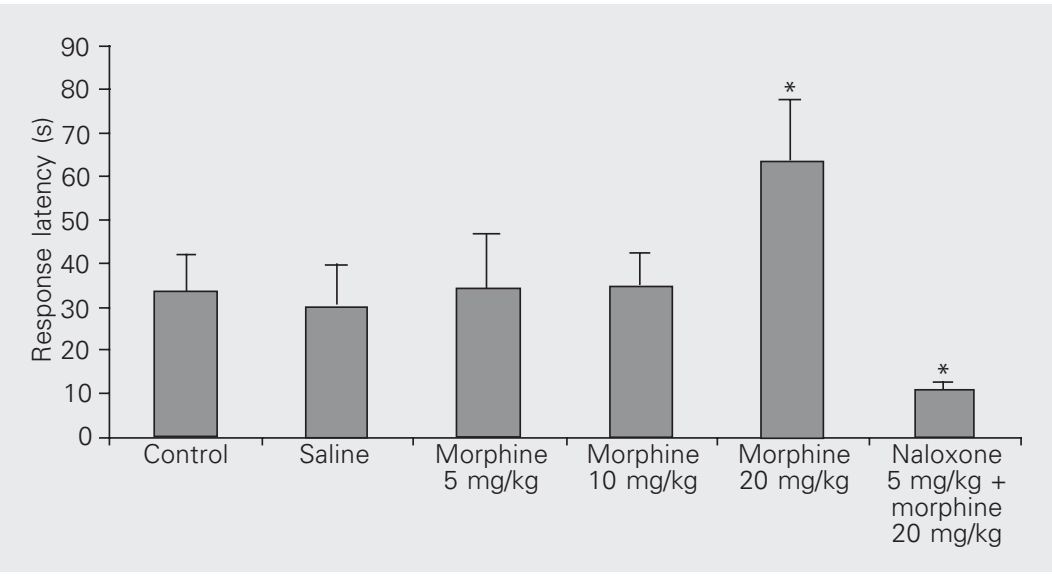

Figure 3. Effect of treatment with morphine, naloxone plus morphine, and saline $(1.0 \mathrm{ml})$ on the response latency after thermal aversive stimuli $\left(50^{\circ} \mathrm{C}\right) 15 \mathrm{~min}$ after injection. Data are reported as means \pm SEM for $\mathrm{N}=9$ animals in all groups. Note the significant difference between the group treated with $20.0 \mathrm{mg} / \mathrm{kg}$ body weight morphine and all other groups ( $\mathrm{P}$ $<0.001)$, and the significant difference between the naloxone plus morphine-treated group and all other groups $(P<0.01)$. The vertical axis shows the response latency. ${ }^{*} P<0.01$ (ANOVA followed by the Tukey test).

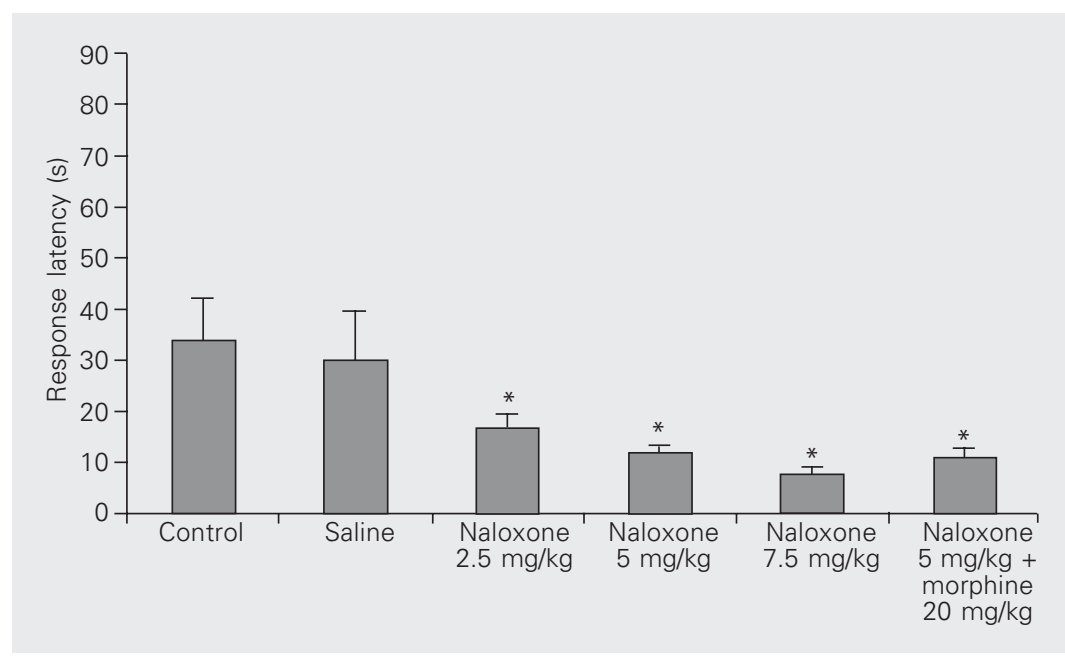

Figure 4. Effect of naloxone, naloxone plus morphine, and saline $(1.0 \mathrm{ml})$ on the response latency after thermal aversive stimuli $\left(50^{\circ} \mathrm{C}\right) 15 \mathrm{~min}$ after injection. Data are reported as means \pm SEM for $N=9$ animals in all groups. ${ }^{*} \mathrm{P}<0.05$ compared to control and salinetreated groups (ANOVA followed by the Tukey test). No significant difference was observed between the groups treated with different naloxone doses. 
differed significantly $(\mathrm{P}<0.001)$ from that of the animals treated with morphine or saline and control, but not among the groups injected with naloxone (Figure 3).

The snails injected with saline alone displayed an average response latency of $29.1 \mathrm{~s}$ and a behavior similar to that of the control group. Also, there was no significant difference between the groups treated with saline or 5.0 and $10.0 \mathrm{mg} / \mathrm{kg}$ body weight morphine in terms of response latency.

\section{Discussion}

In the present study, we examined the behavior of the snail M. abbreviatus after the application of thermal stimuli and the effects of morphine and the antagonist naloxone on thermal avoidance behavior. The snails showed exploratory behavior at ambient temperature $\left(22^{\circ} \mathrm{C}\right)$ or non-thermal stress $\left(30^{\circ} \mathrm{C}\right)$, but a stereotyped behavior at $50^{\circ} \mathrm{C}$. These results were similar to those obtained with other species of gastropods $(4,7)$.

M. abbreviatus displayed exploratory behavior without locomotion when placed on the nonfunctional hot plate $\left(22^{\circ} \mathrm{C}\right)$ in relation to the animals in their habitat (cages). The exploratory behavior consisted of movements of the H-F complex as well as of the oral tentacles and labial palps. The latter structures showed retraction at first contact with the substrate and were immediately protracted, subsequently exhibiting a tentacular palpation of the substrate. This exploratory behavior was also described in the Helix species, with satiated animals usually showing no locomotion (5). Also, the avoidance behavior was not observed at similar hot plate, (nonfunctional) temperatures in C. nemoralis, $M$. sanctipauli, $H$. aspersa or L. maximus $(2,4,7,9,18)$.

The pulmonate snail M. abbreviatus, when exposed to thermal stress $\left(50^{\circ} \mathrm{C}\right)$, presented withdrawal behavior characterized by lifting of the H-F complex, with an average response latency of $33 \mathrm{~s}$. This behavior was quite different from that observed at $22^{\circ}$ and $30^{\circ} \mathrm{C}$. This withdrawal or avoidance behavior has also been identified in other gastropods, such as $C$. nemoralis, $M$. sanctipauli, $H$. aspersa, and L. maximus $(2,4,7,17,18)$, although some differences were noted. Of particular note were the latency times for snails to display the $\mathrm{H}-\mathrm{F}$ lifting response $(C$. nemoralis, 5-6 s; M. sanctipauli, 6-8 s, and M. abbreviatus, $33 \mathrm{~s})$. An explanation of the difference in response latency between the two species of Megalobulimus may be the time of day when the snails were stimulated. In the nociception of $C$. nemoralis, a lightdark rhythm of thermal response latency was found, with latency being longer during the mid-dark period than during the mid-light period (19). Nevertheless, the experiments on the two Megalobulimus species were carried out during the same mid-light period $(4,20)$.

During thermal stress, M. abbreviatus developed a complex behavior similar to that described for $C$. nemoralis (17). These snails displayed biphasic avoidance behavior including protraction and retraction of the body. In the first phase of this behavior, $C$. nemoralis displayed complete withdrawal of the body into the shell, while $M$. abbreviatus displayed partial withdrawal consisting of elevation of the ventral-medial region of the anterior aspect of the body, supported only by the lateral parapodium. These movements involve the columellar, tentacular retractor and pedal muscles (21), which are controlled by neurons located in the pedal and cerebral ganglia $(22,23)$. Thus, we can conclude that M. abbreviatus showed a sequence of escape behaviors similar to that shown by $C$. nemoralis (17).

The color and consistency of the mucus secretion varied according to the thermal stimulus. In M. abbreviatus stimulated at $22^{\circ}$ or $30^{\circ} \mathrm{C}$ no modification was detected. However, after thermal stress a copious, thick, yellowish mucus secretion, and swelling of the foot were observed, indicating a prob- 
able inflammatory process in the foot.

Our findings showed that morphine elicited an increase in the latency of the aversive behavior and that naloxone blocked this behavior causing an antiaversive effect in $M$. abbreviatus, as has been described in vertebrates and other invertebrates $(1,2,4,7,9,18$, 20,24-27). The fact that naloxone suppressed the analgesic response of morphine and reduced the nociceptive response of the endogenous peptides suggests the existence of an opiate mechanism in M. abbreviatus.

In addition, it is well known that morphine produces behavioral inactivity and muscular rigidity in both humans and animals $(26,28)$. At low doses it enhances locomotion, while at higher doses it produces a biphasic effect. In the first phase, spontaneous activity is reduced and in the second phase, locomotion increases. At the highest doses, morphine produces a state characterized by muscular rigidity and lack of spontaneous activity $(29,30)$.

Both morphine and naloxone affected the thermal avoidance behavior of M. abbre- viatus. These results, together with the detection of Met-enkephalin-like immunoreactivity in the central nervous system of this snail (11), provide evidence of the involvement of an endogenous opioid system in the control of thermal withdrawal behavior and nociception. On other hand, it is well known that one of the most difficult problems in neurobiology is functional identification of neurons involved in a network underlying certain behaviors (31). Thus, this experimental model can be used for subsequent investigations about nociception to be conducted in our laboratory, such as the detection of the nociceptive pathway and of the neurotransmitters and peptides involved in this circuit.

\section{Acknowledgments}

We are grateful to Dr. Alberto A. RasiaFilho (Fundação Faculdade Federal de Ciências Médicas de Porto Alegre) for valuable comments on the manuscript and to Antonio. G. Severino for technical assistance.

\section{References}

1. Kavaliers M (1988). Evolutionary and comparative aspects of nociception. Brain Research Bulletin, 21: 923-932.

2. Kavaliers M, Hirst M \& Teskey GC (1983). A functional role for an opiate system in snail thermal behavior. Science, 220: 99-101.

3. Walters ET (1987). Multiple sensory neuronal correlates of sitespecific sensitization in Aplysia. Journal of Neuroscience, 7: 408417.

4. Romero SMB, Hoffmann A \& Menescal de Oliveira L (1994). Is there an opiate receptor in the snail Megalobulimus sanctipauli? Action of morphine and naloxone. Comparative Biochemistry and Physiology, 107C: 37-40.

5. Balaban PM (1993). Behavioral neurobiology of learning in terrestrial snails. Progress in Neurobiology, 41: 1-19.

6. Hirst $M$ \& Kavaliers $M$ (1987). Levorphanol but not dextrorphan suppresses the foot-lifting response to an aversive thermal stimulus in the terrestrial snail, Cepaea nemoralis. Neuropharmacology, 26: 121-123.

7. Kavaliers M \& Hirst M (1986). Naloxone-reversible stress-induced feeding and analgesia in the slug Limax maximus. Life Sciences, 38: 203-209.

8. Nestler EJ, Hyman SE \& Malenka RS (2001). Molecular Neurophar- macology. A Foundation for Clinical Neuroscience. McGraw-Hill Companies, Inc., New York.

9. Kavaliers M (1987). Evidence for opioid and non-opioid forms of stress-induced analgesia in the snail, Cepaea nemoralis. Brain Research, 410: 111-115.

10. Elekes K, Stefano GB \& Carpenter DO (1993). Enkephalin-like immunoreactive neurons in the central nervous system of gastropods (Helix pomatia, Lymnaea stagnalis, Aplysia californica): a comparative immunohistochemical study. Cell and Tissue Research, 272: 257-272.

11. Zancan DM (1996). Localização de mediadores químicos nos gânglios nervosos centrais e tentaculares e inervação da glândula corpo dorsal do caracol pulmonado Megalobulimus oblongus. Doctoral thesis, Programa de Pós-graduação em Ciências Biológicas: Fisiologia, Universidade Federal do Rio Grande do Sul, Porto Alegre, RS, Brazil.

12. Naranjo RM, Mellstrom B, Achaval M \& Sassone-Corsi P (1991). Molecular pathways of pain: Fos/jun-mediated activation of a noncanonical AP-1 site in the prodynorphin gene. Neuron, 6: 607617.

13. Bullitt $E$ (1989). Induction of $c$-fos-like protein within the lumbar 
spinal cord and thalamus of the rat following peripheral stimulation. Brain Research, 493: 391-397.

14. Kavaliers M, Perrot-Sinal TS, Desjardins DC, Cross-Mellor SK \& Wiebe JP (2000). Antinociceptive effects of the neuroactive steroid 3alpha-hydroxy-5alpha-pregnan-20-one and progesterone in the land snail, Cepaea nemoralis. Neuroscience, 95: 807-812.

15. Kavaliers M \& Perrot-Sinal TS (1996). Pronociceptive effects of the neuropeptide, nociceptin, in the land snail Cepaea nemoralis. Peptides, 17: 763-768.

16. Penha MA (2001). Um modelo de comportamento aversivo térmico em Megalobulimus oblongus e a ação de fármacos nos sistemas opióide e serotoninérgico. Master's thesis, Programa de Pósgraduação em Neurociências, Universidade Federal do Rio Grande do Sul, Porto Alegre, RS, Brazil.

17. Dyakonova VE, Elofsson R, Calberg M \& Sakharov DA (1995). Complex avoidance behavior and its neurochemical regulation in the land snail Cepaea nemoralis. General Pharmacology, 26: 773-777.

18. Gutiérrez R (1992). Effects of naloxone on membrane potential of identified neurons of Helix aspersa. Comparative Biochemistry and Physiology, 101C: 425-431.

19. Yu N \& Kavaliers M (1991). Pertussis toxin reduces the day-night rhythm of nociception and mu and kappa opioid peptide-mediated antinociception in the snail Cepaea nemoralis. Peptides, 12: 877881.

20. Kavaliers M (1992). Opioid systems, behavioral thermoregulation and shell polymorphism in the land snail Cepaea nemoralis. Journal of Comparative Physiology, 162B: 172-178.

21. Faccioni-Heuser MC, Zancan DM, Lopes C \& Achaval M (1999). The pedal muscle of the land snail Megalobulimus oblongus (Gastropoda, Pulmonata): an ultrastructure approach. Acta Zoologica, 80: 325337.

22. Faccioni-Heuser MC, Puperi C, Malysz T, Zancan DM \& Achaval M (2001). Neurônios do gânglio pedal envolvidos na inervação da musculatura pediosa do caracol terrestre Megalobulimus oblongus.
Proceedings of the XVI Annual Meeting of FESBE, Caxambu, MG, Brazil, August 29-September 1, 273

23. Malysz T, Faccioni-Heuser MC, Puperi C, Achaval M \& Zancan DM (2001). Identificação de neurônios envolvidos na inervação da região posterior do pé do caracol Megalobulimus oblongus. Proceedings of the XVI Annual Meeting of FESBE, Caxambu, MG, Brazil, August 29-September 1, 273.

24. O'Callagan JF \& Holtzman SG (1975). Quantification of the analgesic activity of narcotic antagonists by a modified hot-plate procedure. Journal of Pharmacology and Experimental Therapeutics, 192 : 497-505.

25. Warizi R (1976). Morphine effects on cholinergic synaptic transmission in Aplysia: evidence for receptor blockage. Comparative Biochemistry and Physiology, 55C: 95-102.

26. Martin WR (1984). Pharmacology of opioids. Pharmacological Reviews, 35: 284-323.

27. Kavaliers M \& Ossenkopp KP (1993). Repeated naloxone treatments and exposures to weak 60-Hz magnetic fields have "analgesic" effects in snails. Brain Research, 620: 159-162.

28. Tzsenchtke TM \& Schmidt WJ (1996). Morphine-induced catalepsy is augmented by NMDA receptor antagonists but is partially attenuated by an AMPA receptor antagonist. European Journal of Pharmacology, 295: 137-146.

29. Turski L, Havemann U \& Kuschinsky K (1982). Evidence for functional interaction of morphine in substantia nigra and striatum in relation to muscular rigidity in rats. Neuroscience Letters, 28: 291 296.

30. Burrowes WR, Assanah P \& Stefano GB (1983). Behavioral effects of opiates on the land snail Helix aspersa. Life Sciences, 33 (Suppl 1): 381-384

31. Balaban PM (2002). Cellular mechanisms of behavioral plasticity in terrestrial snails. Neuroscience and Biobehavioral Reviews, 26: 597630. 